УДК 622.323'156(571.16)

\title{
МИНЕРАЛОГО-ГЕОХИМИЧЕСКАЯ СПЕЦИФИКА БУРОВЫХ ШЛАМОВ НЕФТЯНЫХ МЕСТОРОЖДЕНИЙ НА ПРИМЕРЕ ОБЪЕКТОВ ТОМСКОЙ ОБЛАСТИ
}

\author{
Климова Алена Андреевна', \\ klimovalena777@mail.ru \\ Язиков Егор Григорьевич1, \\ yazikoveg@tpu.ru \\ Шайхиев Ильдар Рафаилович², \\ ildar.shaihiev@mail.ru \\ 1 Национальный исследовательский Томский политехнический университет, \\ Россия, 634050, г. Томск, пр. Ленина, 30. \\ 2 Общество с ограниченной ответственностью «Газпромнефть-Восток», \\ Россия, 634045, г. Томск, ул. Нахимова, 13а, стр. 1.
}

\begin{abstract}
Актуальность исследования обусловлена слабой изученностью минералогического, элементного состава и токсичности буровых шламов, образованных в процессе строительства скважин на нефтяных месторождениях.

Цель: выявить минералогическую и геохимическую специфику буровых шламов, определить наличие токсичности данного вида отхода с использованием современных методов исследований.

Методы: рентгеновская порошковая дифрактометрия; масс-спектрометрия с индуктивно-связанной плазмой; сканирующая электронная микроскопия; биотестирование.

Результаты. В пробах бурового шлама исследуемых нефтяных месторождений Томской области определены общие минералы - квари, альбит, мусковит и кальцит, что указывает на схожий состав исходных вмещающих пород. В буровых шламах выделяется следующая геохимическая специализация, выраженная в повышенном концентрировании таких химических элементов, как Pb, Zn, Сu. Главным образом, элементы относятся к тяжелым металлам I, II и III класса опасности. Величина суммарного показателя загрязнения показывает, что большинство проб шлама относится к низкой степени загрязнения. Однако для образиов с действующих шламовых амбаров характерна средняя степень загрязнения. Выявленные минеральные фазы представлены оксидами железа, свинца, цинка, сульфидом железа, сульфатом бария. Были обнаружены частицы железа и свинца сферической формы. В иелом пробы бурового шлама не оказывают токсического действия на тест-объекты: Daphia magna, Scenedesmus quadricauda, Drosophila melanogaster. B то же время пробы с эксплуатируемых амбаров оказывают влияние на тест-организм Daphia magna. Таким образом, исследуемые пробы бурового шлама относятся к малоопасным, практически неопасным отходам и не являются потенциально токсичными.
\end{abstract}

\section{Ключевые слова:}

Буровой шлам, шламовый амбар, кустовая площадка, нефртяное месторождение, элементный состав, тяжелые металлы, биотестирование.

\section{Введение}

Строительство нефтяных и газовых скважин является экологически опасным для объектов природной среды, что отмечается в работах различных авторов [1-3]. Наибольшую опасность при проведении буровых работ при строительстве скважин представляет загрязнение территории буровыми отходами, химическими реагентами и продукцией скважин $[2,3]$. Влияние объектов нефтегазового комплекса подробно рассмотрено в аналитическом обзоре [4], в котором приведена информация о загрязняющих веществах, подлежащих контролю, и организации мониторинга за состоянием природной среды на территории нефтепромысла.

Основным хранилищем отходов бурения на этапе строительства объектов нефтепромысла являются шламовые амбары, многие из которых размещены в водоохранных зонах и представляют серьезную угрозу речным, озерным и болотным экосистемам $[2,5]$. Влияние шламовых амбаров как источника поступления сточных вод и отходов бурения в окружающую среду, в частности в болотные экосистемы, рассмот- рено в работах $[2,6,7]$. Установлено, что влияние на болотные экосистемы несущественное при условии правильной эксплуатации шламовых амбаров [6], за исключением вариантов с нарушением обваловок амбаров и аварийных ситуаций, при которых происходит перелив и утечка буровых сточных вод [2].

Цель исследования - выявление минералогической и геохимической специфики буровых шламов, определение наличия токсичности данного вида отхода с использованием современных методов исследований. Объект исследования - отходы бурения (буровой шлам), образованные при бурении эксплуатационных скважин на территории кустовых площадок № 7, 8, 3 Шингинского и Южно-Шингинского месторождений, расположенных на территории Парабельского и Каргасокского районов Томской области (рис. 1).

Химические характеристики буровых отходов в значительной степени зависят от исходного состава пород, а также от технологии бурения, а именно от типа буровых растворов и метода бурения. Таким образом, отходы бурения от каждой буровой деятельности имеют свои химические характеристики [8]. 
Присутствие углеводородов и тяжелых металлов в отходах бурения представляет собой проблему для природной среды, поскольку тяжелые металлы не подвергаются биологическим процессам и сохраня- ются в окружающей среде. Помимо факторов окружающей среды, интенсивность рассматриваемого процесса определяется формами металлов и типами связей с твердофазными компонентами [9].

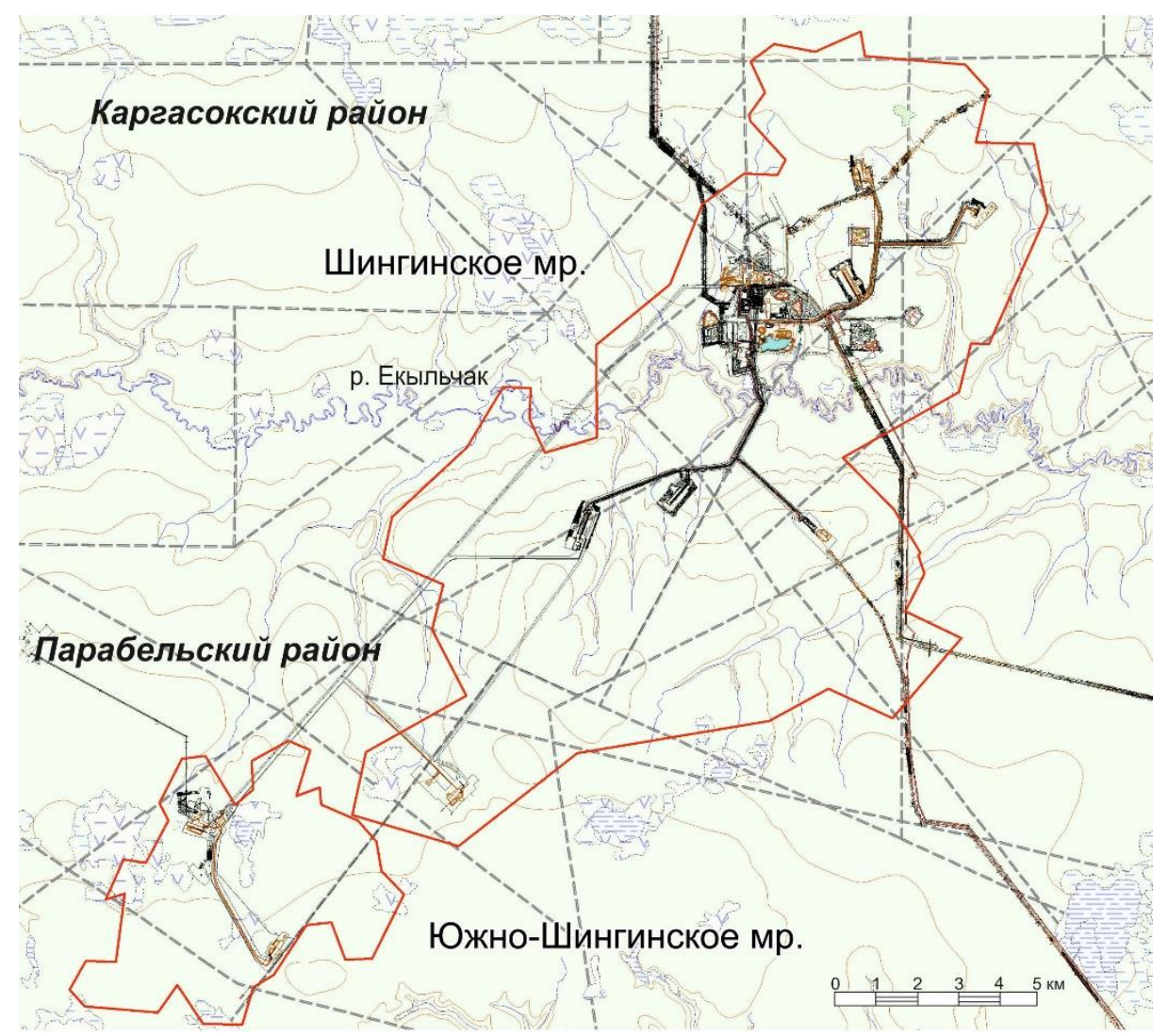

Pис. 1. Фрагмент схемы расположения нефтяных месторождений (Шингинское и Южно-Шингинское) в Томской области

Fig. 1. Fragment of location scheme of oil fields (Shinginskoe and Yuzhno-Shinginskoe) in the Tomsk region

Для смазки и охлаждения бурового оборудования, компенсации пластового давления, транспортировки выбуренной породы и решения многих других задач при строительстве скважин применяются буровые растворы [10]. Они представляют собой суспензию твердых веществ, растворенных в жидкости (например, в воде или в нефти) или в жидких эмульсиях с химическими добавками, которые необходимы для изменения их свойств [11]. Состав буровых растворов является сложным и варьирует в широком диапазоне в зависимости от конкретной скважины и таких условий, как температура, давление, геологическое строение, и других факторов. В большинстве буровых растворов присутствуют металлы, концентрации которых могут варьировать в зависимости от состава базовых ингредиентов и добавок. Ряд металлов в буровых растворах и шламах, потенциально токсичных и вызывающих наибольшую озабоченность, включает As, Ba, Cr, Cd, Cu, Fe, Pb, Hg, Ni, Zn. Некоторые из этих металлов преднамеренно добавляются к буровым растворам в виде солей металлов и органометаллических соединений. Наиболее распространенным металлом в большинстве буровых растворов является Ва (щелочноземельный металл, такой как K и $\mathrm{Sr}$ ). Почти весь барий в буровом растворе присутствует за счет барита $\left(\mathrm{BaSO}_{4}\right)$, который добавляют в раствор для увеличения его плотности [12].

Буровой шлам представлен частицами измельченной породы, почвы и бурового раствора, а также включает различные эмульгаторы, соли и минеральные добавки $[13,14]$. В дополнение к твердым формам буровые шламы содержат небольшое количество жидких и твердых компонентов бурового раствора [15]. Химический состав буровых шламов определяется литологическим составом разбуриваемых пород и реагентами, входящими в состав буровых растворов $[12,16,17]$. Буровые шламы содержат макроэлементы $(\mathrm{Ca}, \mathrm{Mg}, \mathrm{K}, \mathrm{Na})$ и микроэлементы $(\mathrm{Cu}, \mathrm{Co}, \mathrm{Fe}, \mathrm{Mn}, \mathrm{Zn}$, $\mathrm{As}, \mathrm{Al}, \mathrm{Ba}, \mathrm{Cr}, \mathrm{Cd}, \mathrm{Pb}, \mathrm{Ni}, \mathrm{Hg}$ ) [8, 18]. Такие элементы, как $\mathrm{Ba}, \mathrm{Ni}, \mathrm{Co}, \mathrm{Cu}$ и $\mathrm{Zn}$, могут представлять угрозу, связанную с долговременной подвижностью [19].

По данным различных авторов, содержание тяжелых металлов в буровых шламах варьируется от минимальных до повышенных концентраций [20-24]. Большинство металлов, связанных со шламами, находятся в неподвижных формах в минералах из геологических образований. Так, согласно исследованиям, барий более распространен в буровом растворе, чем в 
буровых шламах, как и ожидалось из-за его обилия в буровых растворах, свинец и цинк более распространены в шламах, чем в буровых растворах, что указывает на высокие концентрации в пробуренном пласте или загрязнение шлама обсадными трубами [14].

Исследование [20] показывает, что в буровых шламах содержится большое количество элементов I и II класса опасности, концентрации которых во много раз превышают предельно допустимые концентрации (ПДК) в почве. Авторы делают выводы, что присутствие тяжелых металлов в буровом шламе связано с поступлением из выбуренной породы, что подтверждалось аналитическими методами исследования водного и кислотного экстрактов.

Согласно исследованию [9], тяжелые металлы в буровых шламах были в основном связаны с органической фракцией. Отмечается, что металлы, присутствующие в буровых шламах, такие как $\mathrm{Cu}, \mathrm{Ni}, \mathrm{Zn}, \mathrm{Cd}$ и Со, связаны в основном с окисляемыми фазами [19]. Кроме того, металлы органической фракции характеризуются долговременной подвижностью, что указывает на необходимость постоянного мониторинга отложений, содержащих отходы этого типа. При исследовании и оценке буровых шламов большое внимание уделяется валовому содержанию токсичных компонентов [25], большая часть металлов находится в нерастворимой форме, как правило, в структуре кристаллической решетки минералов вмещающих пород $[14,21,25]$. Также следует учитывать подвижную форму тяжелых металлов $[25,26]$, так как исследования показывают, что буровой шлам может стать источником вторичного загрязнения из-за выноса подвижных форм элементов, входящих в состав отхода.

Подводя итог, необходимо отметить, что помимо нефтепродуктов и минерализованных вод в буровом шламе, тяжелые металлы также являются немаловажным критерием, обуславливающим токсичность данного вида отхода.

\section{Геология}

Шингинское и Южно-Шингинское месторождения располагаются в локальном поднятие юго-западной части Шингинской мезоседловины [27]. Район приурочен к территории Западно-Сибирской плиты, является элементом Урало-Сибирской платформы. Исследуемая территория расположена в Васюганской нефтегазоносной области (НГО) Пудинского нефтегазоносного района (НГР). Верхнеюрский нефтегазоносный комплекс является основным нефтегазоперспективным комплексом данного района, и наиболее продуктивной является надугольная толща васюганской свиты [28].

Согласно фондовым материалам компании ООО «Газпромнефть-Восток», геологический разрез месторождений сложен образованиями складчатого палеозойского фундамента и мощной толщей осадочных терригенных пород мезо-кайнозойского чехла. Мезозойские отложения представлены породами юрской и меловой систем. Отложения юрской системы представлены тюменской, васюганской, георгиевской и баженовской свитами.

\section{Методика исследования}

В мае и августе 2018 г. был проведен отбор проб бурового шлама из шламовых амбаров двух нефтяных месторождений (Южно-Шингинское и Шингинское). Всего было отобрано 5 объединенных проб бурового шлама с пяти шламовых амбаров. На Шингинском месторождении пробы отбирались из шламовых амбаров на кустовых площадках № 7, 8 . На Южно-Шингинском месторождении пробы отбирались с трех амбаров, расположенных на кустовой площадке № 3. Следует отметить, что амбар № 3 на кустовой площадке № 3 и амбар, расположенный на кустовой площадке № 8, на момент отбора проб эксплуатировались. Схема расположения кустовых площадок представлена на рис. 2.

С каждого шламового амбара путем смешения точечных проб, отобранных по периметру амбара, составлялись объединенные пробы. Масса объединенных проб составила не менее 1 кг. Все работы по отбору проб бурового шлама проводились в соответствии с методическими рекомендациями [29]. Подготовка проб буровых шламов к аналитическим исследованиям включала несколько этапов: предварительное просушивание, растирание и просеивание через сито (с диаметром отверстий 1 мм), с последующим истиранием до состояния «пудры» и упаковкой в полиэтиленовые пакетики. Перед исследованием на сканирующем электронном микроскопе пробы бурового шлама были разделены на магнитную, электромагнитную и немагнитную фракции.

Минералогический состав исследуемых проб определялся методом рентгеновской порошковой дифрактометрии на дифрактометре Bruker D2 PHASER в МИНОЦ «Урановая геология» на базе Инженерной школы природных ресурсов НИ ТПУ (консультант Б.Р. Соктоев). Предварительно валовые пробы были измельчены на дробильной установке и растерты в агатовой ступке до пудрообразного состояния. Выделение глинистой составляющей осуществлялась методом отмучивания исходной пробы, с последующим растиранием в агатовой ступке. Изучение минеральных форм элементов в исследуемых буровых шламах проводилось на сканирующем электронном микроскопе Hitachi S-3400N с ЭДС приставкой Bruker XFlash 4010/5010 в МИНОЦ «Урановая геология» (консультант С.С. Ильенок). Исследование проводилось на электронном микроскопе в режиме высокого вакуума с использованием детектора обратнорассеянных электронов. Элементный состав определялся методом масс-спектрометрии с индуктивно связанной плазмой (МС-ИСП) в Химикоаналитическом центре «Плазма», г. Томск.

Полученные результаты были обработаны при помощи программы Microsoft Excel. Кларк концентрации рассчитывался по формуле $\mathrm{Kk}=\mathrm{C} / \mathrm{Ck}$, где где $\mathrm{Kk}-$ кларк концентрации, C - содержание элемента в пробе, мг/кг; $\mathrm{Ck}$ - геохимический кларк земной коры, мг/кг [30]. 


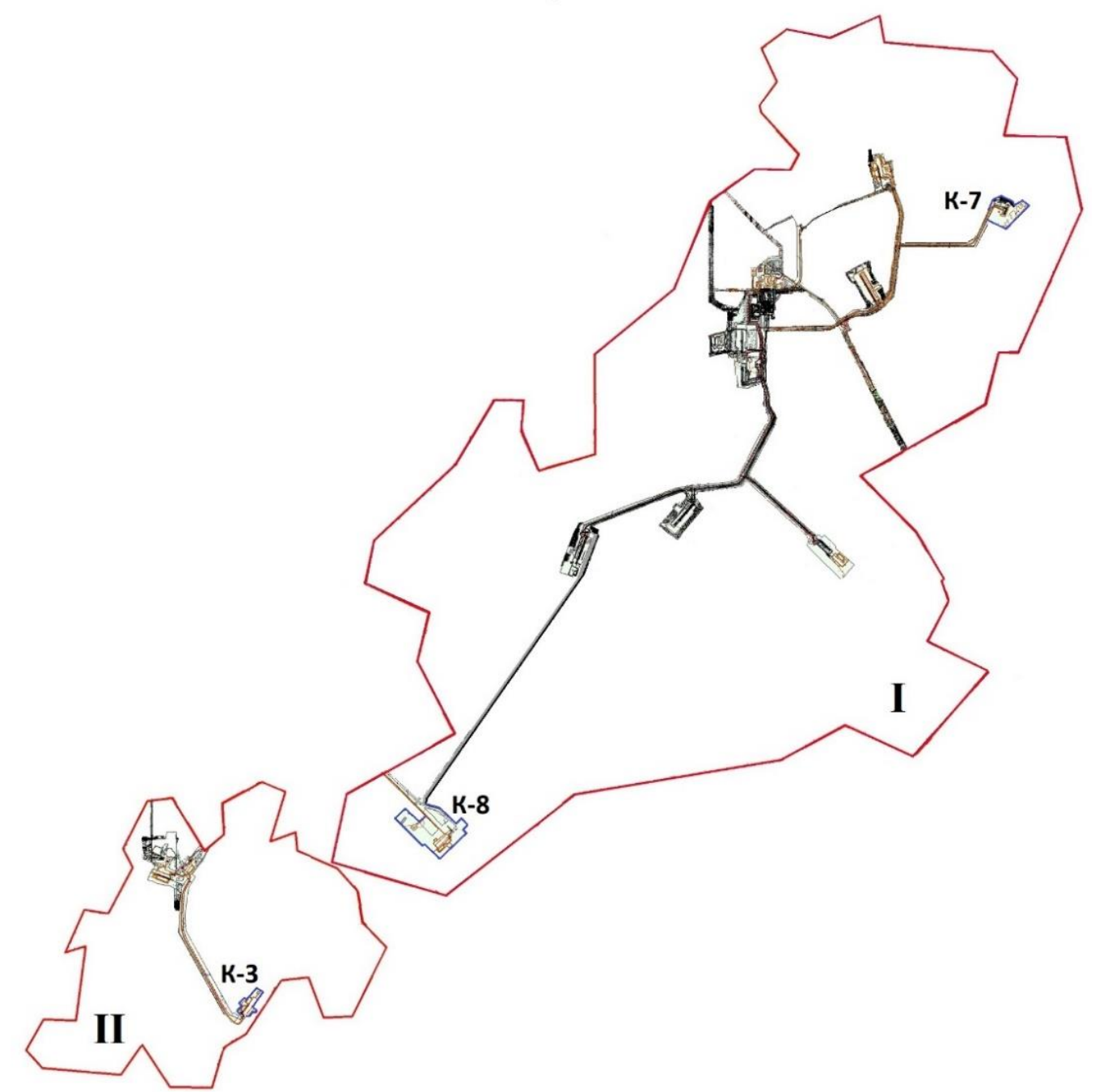

Рис. 2. Схема расположения кустовых площадок на территории нефтяных месторождений I - Шингинское месторождение, II - Южно-Шингинское месторождение; Кустовая площадка № 3 (К-3), Кустовая площадка № 7 (К-7), Кустовая площадка № 8 (К-8)

Fig. 2. Location scheme of well pads within the territory of oil fields: I-Shinginskoe oil field, II - Yuzhno-Shinginskoe oil field; well pad no. 3 (K-3), well pad no. 7 (K-7), well pad no. $8(K-8)$

Также был рассчитан суммарный показатель загрязнения при использовании кларка концентрации (Kk) по формуле:

$$
\mathrm{Zc}=\sum_{\mathrm{i}=1}^{\mathrm{n}} \mathrm{Kk}-(\mathrm{n}-1),
$$

где $\mathrm{Kk}$ - кларк концентрации $i$-го химического элемента; $\mathrm{n}$ - число учитываемых аномальных элементов. Суммарный показатель загрязнения разделяется на категории: низкий - менее 16; средний 16-32, высокий 32-128, очень высокий - более 128 [31].

Токсичность и класс опасности бурового шлама определялись методом биотестирования с использованием трех тест-объектов из разных биологических групп. В аккредитованной лаборатории ОГБУ «Облкомприрода» г. Томска (аналитик А.П. Сороченко) по аттестованным методикам был определен класс опасности исследуемых буровых шламов с помощью биотестирования на двух тест-объектах: Daphnia magna и Scenedesmus quadricauda (Turp.) Breb. Было проана- лизировано 5 объединенных проб бурового шлама с исследуемых шламовых амбаров на каждом тесторганизме.

На базе отделения геологии Инженерной школы природных ресурсов НИ ТПУ был поставлен эксперимент по определению токсичности исследуемых проб бурового шлама на тест-объекте плодовой мушки Drosophila melanogaster. Данный биологический объект позволяет выявить токсичность твердой фазы отхода, в то время как использование Daphnia magna и Scenedesmus quadricauda отображает токсичность водорастворимых соединений отходов. Важным преимуществом мушки Drosophila melanogaster, как тест-объекта, является возможность оценки токсического влияния на следующее поколение на генетическом уровне, через соотношение полов и наличие морфоз.

В процессе биотестирования проб бурового шлама на тест-объекте Drosophila melanogaster изучено 5 объединенных проб и просмотрено более 7000 особей. 
Для постановки эксперимента взяты дрозофилы двух линий yellow (y) и singed (sn). При скрещивании самок yellow с самцами singed в опыте и контроле получены самцы yellow и самки дикого типа. Контрольные и опытные группы формировали одновременно и идентично. В дальнейшем следили за развитием нового поколения. Истертые до пудры пробы бурового шлама добавляли в питательную среду для дрозофил в процентном соотношении 0,2\% (буровой шлам) и 99,8 \% (чистая среда). При этом процентная величина $0,2 \%$ была установлена после определения летальной дозы (LD50). По окончанию эксперимента по оценке токсичности буровых шламов на тест-объект Drosophila melanogaster оценивалось соотношение особей обоих полов в пробах бурового шлама по отношению к контролю.

Был рассчитан показатель, обозначаемый греческой буквой $\chi$, возведенной в квадрат, откуда и получивший свое название критерий хи-квадрат. Вычисляется данный показатель по формуле:

$$
\chi^{2}=\sum \frac{(0-E)^{2}}{E}
$$

где $\mathrm{O}$ - фактически наблюдаемое число особей в данном классе; Е - теоретически ожидаемое число таких особей; $\Sigma$ - сумма результатов по всем классам [32]. Оценка степени соответствия проводилась с помощью критерия хи-квадрат и сравнения полученной величины с табличным значением. Существуют значения $\chi^{2}$, определяющие границы, ниже которых полученные значения остаются в рамках случайных отклонений. Принято считать допустимой границей вероятность 0,05. Также учитывается число степеней свободы, равное числу классов, уменьшенному на единицу. В нашем случае оно равно 1, т. к. в эксперименте участвует две линии мух. При вероятности значения 0,05 и степени свободы, равной 1 , табличное значение равно 3,84, ниже которого теоретическое отклонение от фактического не будет наблюдаться.

\section{Результаты и их обсуждение}

По данным рентгенофазового анализа в составе исследуемых проб бурового шлама были определены минералы: кварц, альбит, анортоклаз, мусковит, клинохлор, кальцит. Наличие в каждой пробе общих минералов, таких как кварц, альбит, мусковит и кальцит, указывает на схожий состав исходных вмещающих пород. Кварц и альбит преобладают в составе исследуемых проб бурового шлама с Южно-Шингинского и Шингинского месторождений. Тем не менее, стоит отметить различия в минеральном составе проб. В буровом шламе с амбаров Южно-Шингинского месторождения фиксируется кальцит, в то время как в пробах с Шингинского месторождения присутствует магнезиальный кальцит. Существуют различия в минеральном составе проб с Южно-Шингинского месторождения: в пробе амбара № 3 отсутствует анортоклаз, а в амбаре № 2 не выявлен клинохлор, в то же время в пробе амбара № 1 диагностированы все ранее перечисленные минералы. Результаты анализа представлены в табл. 1.
Таблица 1. Минералогический состав бурового шлама Table 1. Mineralogical composition of drill cuttings

\begin{tabular}{|c|c|c|c|c|c|}
\hline \multirow{6}{*}{$\begin{array}{c}\text { Наименование } \\
\text { минерала } \\
\text { Mineral name }\end{array}$} & \multicolumn{3}{|c|}{$\begin{array}{c}\text { Южно-Шингинское } \\
\text { месторождение } \\
\text { Yuzhno-Shinginskoe } \\
\text { field (3) }\end{array}$} & \multicolumn{2}{|c|}{$\begin{array}{c}\text { Шингинское } \\
\text { месторождение } \\
\text { Shinginskoe field } \\
(2) \\
\end{array}$} \\
\hline & \multicolumn{5}{|c|}{ Кустовая площадка/Well pad } \\
\hline & & 3 & & 7 & 8 \\
\hline & \multicolumn{5}{|c|}{ амбар/sludge pit } \\
\hline & 1 & 2 & 3 & & \\
\hline & \multicolumn{5}{|c|}{ содержание/content, \% } \\
\hline Кварц /Quartz & 52,7 & 56,9 & 45 & 56,8 & 63,3 \\
\hline Альбит /Albite & 18,6 & 14,8 & 27,7 & 18,7 & 19,6 \\
\hline $\begin{array}{l}\text { Анортоклаз } \\
\text { Anorthoclase }\end{array}$ & 10,4 & 9,1 & - & 10 & 9,2 \\
\hline $\begin{array}{l}\text { Мусковит } \\
\text { Muscovite }\end{array}$ & 6,9 & 17,5 & 16,1 & 6,9 & 4,4 \\
\hline $\begin{array}{l}\text { Клинохлор } \\
\text { Klinochlor }\end{array}$ & 6,6 & - & 5,6 & 2,8 & 2,1 \\
\hline Кальцит/Calcite & 4,9 & 1,7 & 5,6 & - & - \\
\hline $\begin{array}{l}\text { Кальцит магнези- } \\
\text { альный } \\
\text { Magnesite Calcite }\end{array}$ & - & - & - & 4,7 & 1,5 \\
\hline
\end{tabular}

Примечание: в скобках - количество проб.

Note: the amount of samples is given in brackets.

Глинистая составляющая отделялась методом отмучивания, с последующей фильтрацией через фильтр и анализом полученной фракции на дифрактометре. Результаты рентгенофазового анализа выделенной составляющей представлены в табл. 2.

Таблица 2. Минералогический состав выделенной фракичи методом отмучивания

Table 2. Mineralogical composition of the selected fraction by elutriation

\begin{tabular}{|c|c|c|c|c|c|}
\hline \multirow{6}{*}{$\begin{array}{c}\text { Наименование } \\
\text { минерала } \\
\text { Mineral name }\end{array}$} & \multicolumn{3}{|c|}{$\begin{array}{c}\text { Южно-Шингинское } \\
\text { месторождение } \\
\text { Yuzhno-Shinginskoe } \\
\text { field (3) }\end{array}$} & \multicolumn{2}{|c|}{$\begin{array}{c}\text { Шингинское } \\
\text { месторождение } \\
\text { Shinginskoe field } \\
\text { (2) }\end{array}$} \\
\hline & \multicolumn{5}{|c|}{ Кустовая площадка/Well pad } \\
\hline & \multicolumn{3}{|c|}{3} & 7 & 8 \\
\hline & \multicolumn{5}{|c|}{ амбар/sludge pit } \\
\hline & 1 & 2 & 3 & & \\
\hline & \multicolumn{5}{|c|}{ содержание/content, \% } \\
\hline Кварц /Quartz & 36,2 & 29,9 & 32,7 & 29,4 & 33,4 \\
\hline Альбит/Albite & 21,7 & 7,3 & 3,2 & 7,8 & 20,5 \\
\hline $\begin{array}{l}\text { Мусковит } \\
\text { Muscovite }\end{array}$ & 24,0 & 16,6 & 17,5 & 19,0 & 26,4 \\
\hline $\begin{array}{l}\text { Каолинит } \\
\text { Kaolinite }\end{array}$ & 10,2 & 5,6 & - & 7,1 & - \\
\hline Кальцит/Calcite & 7,2 & 2,5 & 6,9 & 6,4 & 4,9 \\
\hline Цеолит/Zeolite & 0,7 & 0,2 & 0,2 & 0,5 & - \\
\hline Иллит/Illite & - & 37,9 & 31,8 & 29,8 & - \\
\hline $\begin{array}{l}\text { Клинохлор } \\
\text { Clinochlore }\end{array}$ & - & - & 5,9 & - & 14,4 \\
\hline $\begin{array}{l}\text { Доломит } \\
\text { Dolomite }\end{array}$ & - & - & 1,9 & - & - \\
\hline $\begin{array}{l}\text { Вермикулит } \\
\text { Vermiculite }\end{array}$ & - & - & - & - & 0,3 \\
\hline
\end{tabular}

Примечание: в скобках - количество проб.

Note: the amount of samples is given in brackets.

По данным рентгенофазового анализа в составе отделенной фракции обнаружен глинистый минерал из группы водных силикатов - каолинит, максимальную долю в составе проб занимают слюды, в частности гидрослюды (иллит и вермикулит). 
Для обработки данных, полученных в ходе анализа элементного состава, использовалась описательная статистика в программе Microsoft Excel. Следует отметить, что для ряда элементов (Ru, $\mathrm{Te}, \mathrm{Re}, \mathrm{Se}, \mathrm{In}, \mathrm{Au}, \mathrm{Hg})$ расчет не проводился, т. к. в более $50 \%$ случаев результат анализа был ниже предела обнаружения. В единичных пробах было выявлено содержание селена и золота, так, в пробе амбара № 2 кустовой площадки № 3 Южно-Шингинского месторождения отмечается наличие $\mathrm{Se}$ и $\mathrm{Au}$. B пробе амбара кустовой площадки № 8 Шингинского месторождения также установлен $\mathrm{Se}$. При сравнении среднего содержания химических элементов в пробах бурового шлама из амбаров Шингинского и Южно-Шингинского месторождений отмечается близкое содержание элементов, за исключением ряда элементов. Так, в пробах Южно-Шингинского месторождения среднее содержание мышьяка и цинка выше, чем в пробах с Шингинского месторождения.

Для определения геохимической специализации буровых шламов используется кларк верхней части континентальной коры по [30]. Диаграммы для буровых шламов с Шингинского и Южно-Шингинского нефтяных месторождений представлены на рис. 3,4 . В буровых шламах из амбаров Южно-Шингинского месторождения устанавливаются повышенные концентрации $\mathrm{Pb}, \mathrm{Zn}, \mathrm{Cu}, \mathrm{Mo}, \mathrm{Ag}, \mathrm{W}, \mathrm{Sb}$, As. Динамика накопления элементов в буровом шламе хорошо прослеживается на примере таких элементов, как $\mathrm{Zn}, \mathrm{Pb}, \mathrm{Mo}, \mathrm{Sb}$, для которых фиксируется увеличение концентрации от амбара № 1 к амбару № 3. Содержание элементов в шламе исследуемого амбара № 3 выше, чем в шламе остальных амбаров на данном месторождении. Для буровых шламов с амбаров кустовой площадки № 7 Шингинского месторождения устанавливаются повышенные концентрации $\mathrm{Pb}, \mathrm{Sn}, \mathrm{Sb}, \mathrm{Ag}$, As, кустовой площадки № 8 - $\mathrm{Pb}, \mathrm{Zn}, \mathrm{Sb}, \mathrm{Cu}, \mathrm{Mo}, \mathrm{Ag}$, Be.

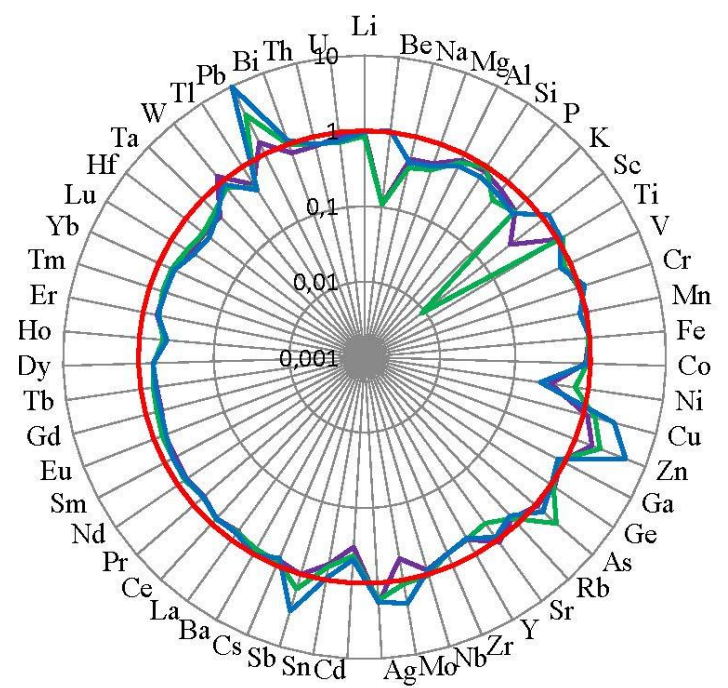

- Амбар 1 -Амбар 2 -Амбар 3 - $\mathrm{Kk}=1$

Рис. 3. Геохимическая специализачия бурового шлама с Южно-Шингинского месторождения, кустовая плошиадка № 3

Fig. 3. Geochemical specialization of drill cuttings from the Yuzhno-Shinginskoe oil field, well pad no. 3

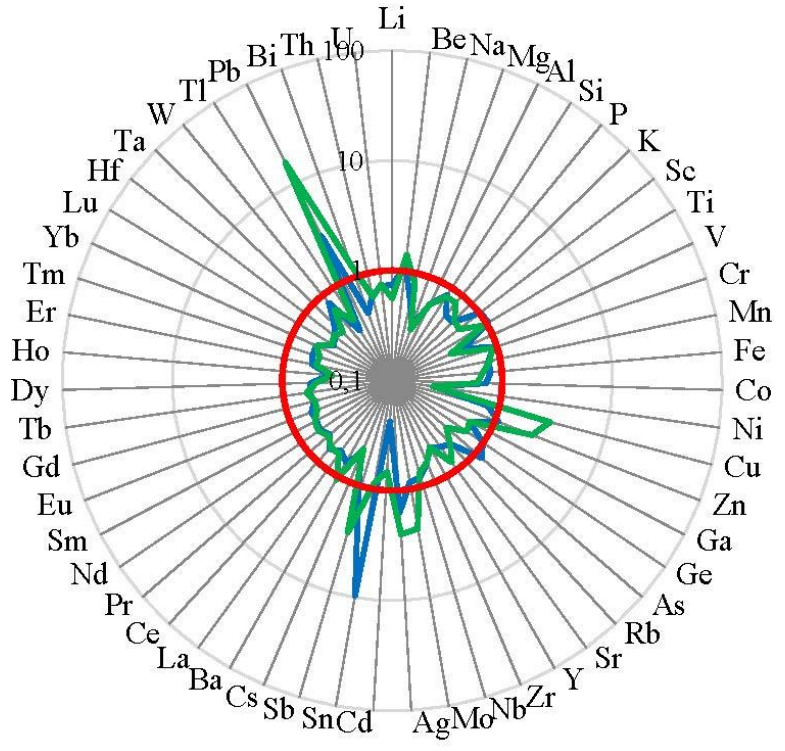

- Амбар, 7 куст - Амбар, 8 куст - $\mathrm{Kk}=1$

Pис. 4. Геохимическая специализачия бурового илама с Шингинского месторождения, кустовая площзадка № 7,8

Fig. 4. Geochemical specialization of drill cuttings from the Shinginskoe oil field, well pad no. 7, 8

В целом элементный состав исследуемых буровых шламов двух месторождений близок. Выделяется геохимическая специализация, в составе которой преобладают тяжелые металлы. В соответствии с полученными данными, можно разделить тяжелые металлы по степени опасности (ГОСТ 17.4.1.02-83): наиболее опасный I класс - As, Pb, Zn; II класс - Cu, Mo, Sb; III класс - Ba, Mn, W.

$\mathrm{B}$ табл. 3 показана специфика накопления химических элементов в буровых шламах. Наибольшая концентрация элементов отмечается в амбаре № 3 Южно-Шингинского месторождения, где выделяются 15 элементов, у которых Kk>1. В то же время накопление химических элементов снижается от эксплуатируемого амбара № 3 к недействующим (амбары № 1, 2). Суммарный показатель загрязнения, рассчитанный по кларку концентрации, показывает, что преимущественно пробы шлама относятся к низкой степени загрязнения, а в отдельных амбарах (Шингинское месторождение, кустовая площадка № 8 и Южно-Шингинское месторождение, кустовая площадка № 3, амбар № 3) - к средней степени загрязнения.

Для установления геохимической специфики исследуемых буровых шламов было решено сравнить ряд элементов с повышенными концентрациями относительно среднего содержания химических элементов в верхней части континентальной коры $(\mathrm{Ti}, \mathrm{Cr}$, $\mathrm{Mn}, \mathrm{Fe}, \mathrm{Cu}, \mathrm{Zn}, \mathrm{As}, \mathrm{Mo}, \mathrm{Ag}, \mathrm{Sn}, \mathrm{Sb}, \mathrm{Ba}, \mathrm{Pb}$ ) с такими показателями, как содержание химических элементов в почвах горизонта $\mathrm{B}, \mathrm{C}$ Васюганской равнины и со средним содержанием химических элементов в осадочных горных породах в целом (табл. 4). 
Известия Томского политехнического университета. Инжиниринг георесурсов. 2020. Т. 331. № 2. 102-114

Климова А.А., Язиков Е.Г., Шайхиев И.Р. Минералого-геохимическая специфика буровых шламов нефртяных месторождений на ...

Таблица 3. Кларки концентрации (Кк) химических элементов относительно среднего состава верхней части континентальной земной коры по Н.А. Григорьеву в буровых шламах нефтяных месторождений (Шингинское и Южно-Шингинское)

Table 3. Clarks of concentration of chemical elements relative to the average composition in the upper continental crust by N.A. Grigoriev in drill cutting oil fields (Shinginskoe and Yuzhno-shinginskoe)

\begin{tabular}{|c|c|c|c|c|c|}
\hline \multirow{6}{*}{$\begin{array}{c}\text { Диапазон } \\
\text { Range }\end{array}$} & \multicolumn{5}{|c|}{ Химические элементы/Chemical elements } \\
\hline & \multicolumn{2}{|c|}{$\begin{array}{l}\text { Шингинское месторождение } \\
\text { Shinginskoe field (2) }\end{array}$} & \multicolumn{3}{|c|}{$\begin{array}{c}\text { Южно-Шингинское месторождение } \\
\text { Yuzhno-Shinginskoe field (3) }\end{array}$} \\
\hline & \multicolumn{5}{|c|}{ Кустовая площадка/Well pad } \\
\hline & 7 & 8 & & 3 & \\
\hline & \multicolumn{5}{|c|}{ амбар/sludge pit } \\
\hline & \multicolumn{3}{|c|}{1} & 2 & 3 \\
\hline$>3$ & Sn, & $\mathrm{Pb}, \mathrm{Cu}$ & - & $\mathrm{Pb}$ & $\mathrm{Pb}, \mathrm{Sb}, \mathrm{Zn}$ \\
\hline $2-3$ & $\mathrm{~Pb}$ & $\mathrm{Sb}, \mathrm{Ag}, \mathrm{Mo}, \mathrm{Zn}$ & - & As, Zn & $\mathrm{Cu}, \mathrm{Mo}$ \\
\hline $1-2$ & $\mathrm{Ag}, \mathrm{Sb}, \mathrm{As}, \mathrm{Be}, \mathrm{Zn}, \mathrm{Ti}, \mathrm{Sc}$ & $\mathrm{Be}, \mathrm{Bi}, \mathrm{Ba}$ & $\begin{array}{c}\mathrm{Ag}, \mathrm{Zn}, \mathrm{Pb}, \mathrm{W}, \mathrm{Cu}, \\
\mathrm{Ge}, \mathrm{Sr}, \mathrm{Ti}, \mathrm{As}, \mathrm{Mn}, \mathrm{Sb}\end{array}$ & $\begin{array}{l}\mathrm{Ag}, \mathrm{Sb}, \mathrm{Cu}, \mathrm{Ti}, \mathrm{Mo} \\
\mathrm{Hg}, \mathrm{Ge}, \mathrm{Nb}, \mathrm{Cr}, \mathrm{Mn}\end{array}$ & $\begin{array}{c}\mathrm{Ag}, \mathrm{As}, \mathrm{Sc}, \mathrm{Cr}, \mathrm{Bi}, \mathrm{Ti} \\
\mathrm{Be}, \mathrm{Ba}, \mathrm{Ge}, \mathrm{Fe}\end{array}$ \\
\hline $0,5-1$ & $\begin{array}{c}\mathrm{Ge}, \mathrm{Cr}, \mathrm{Mo}, \mathrm{Si}, \mathrm{Nb}, \mathrm{W}, \mathrm{Fe}, \\
\mathrm{Cu}, \mathrm{Mn}, \mathrm{Li}, \mathrm{U}, \mathrm{Co}, \mathrm{Ba}, \mathrm{Ce}, \\
\mathrm{Zr}, \mathrm{Th}, \mathrm{Ga}, \mathrm{Nb}, \mathrm{La}, \mathrm{Eu}, \mathrm{Rb}, \\
\mathrm{Sm}, \mathrm{Al}, \mathrm{P}, \mathrm{Tb}, \mathrm{Tm}, \mathrm{Yb}, \mathrm{K}, \\
\mathrm{Pr}, \mathrm{Sr}, \mathrm{Er}, \mathrm{Dy}, \mathrm{Ta}, \mathrm{Gd}, \mathrm{Cs} \\
\text { Na, V, Y }\end{array}$ & $\begin{array}{c}\mathrm{Ti}, \mathrm{Cr}, \mathrm{Sn}, \mathrm{Sr}, \mathrm{P}, \mathrm{Mn}, \mathrm{Si} \\
\mathrm{Na}, \mathrm{U}, \mathrm{Nb}, \mathrm{W}, \mathrm{Cd}, \mathrm{Ce}, \mathrm{Fe}, \\
\mathrm{La}, \mathrm{Ge}, \mathrm{Nd}, \mathrm{Zr}, \mathrm{Sm}, \mathrm{Ga} \\
\mathrm{Tb}, \mathrm{K}, \mathrm{Th}, \mathrm{Rb}, \mathrm{Co}, \mathrm{Al}, \mathrm{Pr}, \\
\mathrm{Sc}, \mathrm{Yb}, \mathrm{Li}, \mathrm{Eu}, \mathrm{Gd}, \mathrm{Er}\end{array}$ & $\begin{array}{c}\mathrm{Ba}, \mathrm{Fe}, \mathrm{Cr}, \mathrm{Li}, \mathrm{Ga}, \mathrm{Nb}, \\
\mathrm{U}, \mathrm{Si}, \mathrm{Co}, \mathrm{Cs}, \mathrm{Al}, \mathrm{V}, \\
\mathrm{Ce}, \mathrm{Rb}, \mathrm{Th}, \mathrm{Bi}, \mathrm{P}, \mathrm{Nd}, \\
\mathrm{La}, \mathrm{Eu}, \mathrm{Sm}, \mathrm{Zr}, \mathrm{Pr}, \mathrm{Dy}, \\
\mathrm{Er}, \mathrm{Tm}, \mathrm{Sn}, \mathrm{Tb}, \mathrm{Yb}, \mathrm{K} \\
\mathrm{Gd}, \mathrm{Y}, \mathrm{Mg}, \mathrm{Tl}, \mathrm{Mo}, \mathrm{Lu}\end{array}$ & $\begin{array}{c}\mathrm{Si}, \mathrm{Bi}, \mathrm{Fe}, \mathrm{Co}, \mathrm{Cs}, \mathrm{Li}, \\
\mathrm{Ba}, \mathrm{Ga}, \mathrm{Ce}, \mathrm{V}, \mathrm{Th}, \mathrm{Rb}, \\
\text { W, Nd, Eu, Sm, Al, } \\
\mathrm{La}, \mathrm{U}, \mathrm{Gd}, \mathrm{Tb}, \mathrm{Pr}, \mathrm{Zr}, \\
\mathrm{Ni}, \mathrm{Tm}, \mathrm{Sn}, \mathrm{Yb}, \mathrm{Dy}, \\
\mathrm{Er}, \mathrm{K}, \mathrm{Y}, \mathrm{Ta}, \mathrm{Lu}, \mathrm{Sr}, \mathrm{Hf}\end{array}$ & $\begin{array}{c}\mathrm{Li}, \mathrm{Sn}, \mathrm{Co}, \mathrm{Nb}, \mathrm{Sr}, \mathrm{W}, \\
\mathrm{Mn}, \mathrm{Ce}, \mathrm{Ga}, \mathrm{Th}, \mathrm{Cs}, \mathrm{La}, \\
\text { U, Sm, Nd, V, Rb, Si, } \\
\mathrm{Pr}, \mathrm{Zr}, \mathrm{Eu}, \mathrm{Al}, \mathrm{Dy}, \mathrm{Tb}, \\
\mathrm{Er}, \mathrm{Gd}, \mathrm{P}, \mathrm{Tm}, \mathrm{Yb}, \mathrm{Y}, \\
\text { K, Ta }\end{array}$ \\
\hline$<0,5$ & $\begin{array}{c}\text { Hf, } \mathrm{Bi}, \mathrm{Lu}, \mathrm{Hg}, \mathrm{Ho}, \mathrm{Tl}, \\
\mathrm{Mg}, \mathrm{Ni}, \mathrm{Cd}\end{array}$ & $\begin{array}{l}\text { Y, Tm, Dy, Cs, Hf, As, Tl, } \\
\text { Lu, Ta, Hg, V, Ho, Mg, Ni }\end{array}$ & $\begin{array}{l}\mathrm{Na}, \mathrm{Hf}, \mathrm{Ta}, \mathrm{Ho}, \mathrm{Hg} \\
\mathrm{Cd}, \mathrm{Ni}, \mathrm{Sc}, \mathrm{Be}\end{array}$ & $\begin{array}{c}\mathrm{P}, \mathrm{Ho}, \mathrm{Tl}, \mathrm{Cd}, \mathrm{Mg}, \mathrm{Na}, \\
\mathrm{Be}, \mathrm{Sc}\end{array}$ & $\begin{array}{l}\mathrm{Cd}, \mathrm{Mg}, \mathrm{Lu}, \mathrm{Na}, \mathrm{Tl}, \\
\mathrm{Ho}, \mathrm{Hf}, \mathrm{Hg}, \mathrm{Ni}\end{array}$ \\
\hline $\mathrm{Zc}$ & 12,78 & 24,85 & 3,81 & 8,54 & 20,77 \\
\hline
\end{tabular}

Примечание: в скобках - количество проб.

Note: the amount of samples is given in brackets.

Таблица 4. Среднее содержание химических элементов (мг/кг) в пробах бурового шлама, в почве горизонта В, С, 8 осадочных горных породах и в верхней части континентальной коры

Table 4. Average content of chemical elements in samples of drill cuttings in the soil of horizon B, $C$, in sedimentary rocks and in the upper part of the continental crust

\begin{tabular}{|c|c|c|c|c|c|c|}
\hline \multirow[b]{2}{*}{ 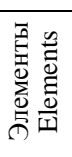 } & \multicolumn{2}{|c|}{ Данные автора/Author data } & \multicolumn{2}{|c|}{ [33] } & \multicolumn{2}{|l|}{ [30] } \\
\hline & $\begin{array}{c}\text { Шингинское } \\
\text { месторождение } \\
\text { Shinginskoe field (2) }\end{array}$ & $\begin{array}{c}\text { Южно-Шингинское } \\
\text { месторождение } \\
\text { Yuzhno-Shinginskoe field (3) }\end{array}$ & $\begin{array}{c}\text { Горизонт В } \\
(70-80 \mathrm{~cm}) \\
\text { Horizon B } \\
(70-80 \mathrm{~cm}) \\
\end{array}$ & $\begin{array}{c}\text { Горизонт С } \\
(155-165 \mathrm{~cm}) \\
\text { Horizon C } \\
(155-165 \mathrm{~cm}) \\
\end{array}$ & $\begin{array}{c}\text { Осадочная } \\
\text { горная порода } \\
\text { Sedimentary } \\
\text { rock } \\
\end{array}$ & $\begin{array}{l}\text { Кларк } \\
\text { Clark }\end{array}$ \\
\hline $\mathrm{Ti}$ & $\frac{3892,0 \pm 239,36}{(3652,64-4131,36)}$ & $\frac{4417,41 \pm 132,82}{(4264,58-4681,98)}$ & 3400,00 & 3000,00 & 3500,00 & 3930 \\
\hline $\mathrm{Cr}$ & $\frac{83,98 \pm 1,95}{(82,04-85,93)}$ & $\frac{97,03 \pm 5,63}{(89,73-108,1)}$ & 125,00 & 125,00 & 76,60 & 92,4 \\
\hline $\mathrm{Mn}$ & $\frac{609,2 \pm 12,69}{(596,51-621,88)}$ & $\frac{729,31 \pm 48,18}{(633,4-785,31)}$ & 900,00 & 800,00 & 730,00 & 770 \\
\hline $\mathrm{Fe}, \%$ & $\frac{2,96 \pm 0,24}{(2,71-3,2)}$ & $\frac{3,99 \pm 0,048}{(3,91-4,08)}$ & 4,5 & 4,0 & 3,54 & 4,06 \\
\hline $\mathrm{Cu}$ & $\frac{74,63 \pm 43,87}{(30,76-118,5)}$ & $\frac{68,19 \pm 17,94}{(44,59-103,39)}$ & 44,00 & 36,00 & 31,00 & 39 \\
\hline $\mathrm{Zn}$ & $\frac{127,39 \pm 46,13}{(81,26-173,52)}$ & $\frac{230,02 \pm 81,5}{(129,81-391,45)}$ & 90,00 & 75,00 & 69,00 & 75 \\
\hline As & $\frac{4,61 \pm 2,11}{(2,5-6,71)}$ & $\frac{8,79 \pm 2,16}{(5,83-13,0)}$ & 9,00 & 7,00 & 7,70 & 5,6 \\
\hline Mo & $\frac{2,49 \pm 1,13}{(1,35-3,62)}$ & $\frac{1,93 \pm 0,71}{(0,8-3,23)}$ & 10,30 & 5,40 & 1,53 & 1,56 \\
\hline $\mathrm{Ag}$ & $\frac{0,22 \pm 0,05}{(0,17-0,28)}$ & $\frac{0,2 \pm 0,01}{(0,19-0,2)}$ & H.о. & н.о. & 0,11 & 0,11 \\
\hline Sn & $\frac{18,29 \pm 15,24}{(3,06-33,53)}$ & $\frac{2,59 \pm 0,36}{(2,15-3,3)}$ & H.о. & н.о. & 2,7 & 3,5 \\
\hline $\mathrm{Sb}$ & $\frac{1,61 \pm 0,61}{(1,0-2,22)}$ & $\frac{1,58 \pm 0,54}{(0,81-2,62)}$ & H.o. & Н.о. & 0,89 & 0,81 \\
\hline $\mathrm{Ba}$ & $\frac{457,32 \pm 94,24}{(363,08-551,56)}$ & $\frac{481,23 \pm 26,0}{(429,92-514,18)}$ & 460,00 & 420,00 & 410,00 & 510 \\
\hline $\mathrm{Pb}$ & $\frac{161,96 \pm 112,83}{(49,13-274,79)}$ & $\frac{85,36 \pm 42,18}{(25,07-166,6)}$ & 18,00 & 17,00 & 12,00 & 17 \\
\hline
\end{tabular}

Примечание: среднее содержание химических элементов в пробах бурового илама по данным масс-спектрометрии с индуктивно-связанной плазмой (ИСП-МС), \pm - станд. ошибка; в знаменателе - (тіп-тах). [33] - содержание химических элементов в дерново-подзолистых почвах южной тайги Западной Сибири (Васюганская равнина). [30] Осадочная горная порода - среднее содержание химических элементов в осадочных горных породах в целом; кларк среднее содержание химических элементов в верхней части континентальной коры.

Note: average content of chemical elements in samples of drill cuttings according to mass spectrometry with inductively coupled plasma (ICP-MS), \pm- standard error; in the denominator - (min-max). [33] content of chemical elements in sod-podzolic soils of the southern taiga of Western Siberia (Vasyugan plain). [30] Sedimentary rock - average content of chemical elements in sedimentary rocks as a whole; Clark-average content of chemical elements in the upper part of the continental crust. 
Содержание таких элементов, как $\mathrm{Pb}, \mathrm{Zn}, \mathrm{Cu}$ превышает среднее содержание в почве (горизонт В и С), в осадочных горных породах в целом и также среднее содержание химических элементов в верхней части континентальной коры. Элементы Ва и Ті отмечены в повышенном количестве относительно рассматриваемых горизонтов почвы и осадочных горных пород.

Пробы бурового шлама были разделены на магнитную, электромагнитную и немагнитную фракции. Доля магнитной и электромагнитной фракции составила менее $0,5 \%$. Полученное процентное соотношение представлено в табл. 5.

Таблица 5. Прочентное соотночение магнитной, электромагнитной и немагнитной фракций в пробах бурового илама

Table 5. Percentage ratio of magnetic, electromagnetic and non-magnetic fractions in samples of drill cuttings

\begin{tabular}{|c|c|c|c|c|c|}
\hline \multirow{5}{*}{$\begin{array}{l}\text { Фракция } \\
\text { Fraction }\end{array}$} & \multicolumn{2}{|c|}{$\begin{array}{c}\text { Шингинское } \\
\text { Shinginskoe (2) }\end{array}$} & \multicolumn{3}{|c|}{$\begin{array}{l}\text { Южно-Шингинское } \\
\text { Yuzhno-Shinginskoe (3) }\end{array}$} \\
\hline & \multicolumn{5}{|c|}{ Кустовая площадка/Well pad } \\
\hline & 7 & 8 & \multicolumn{3}{|c|}{3} \\
\hline & \multicolumn{5}{|c|}{ амбар/sludge pit } \\
\hline & \multicolumn{3}{|c|}{1} & 2 & 3 \\
\hline $\begin{array}{l}\text { Магнитная } \\
\text { Magnetic }\end{array}$ & 0,10 & 0,42 & 0,21 & 0,02 & 0,12 \\
\hline $\begin{array}{l}\text { Электромагнитная } \\
\text { Electromagnetic }\end{array}$ & 0,08 & 0,06 & 0,21 & 0,01 & 0,24 \\
\hline $\begin{array}{l}\text { Немагнитная } \\
\text { Non-magnetic }\end{array}$ & 99,82 & 99,52 & 99,58 & 99,97 & 99,64 \\
\hline
\end{tabular}

Примечание: в скобках-количество проб.

Note: the amount of samples is given in brackets.

Далее каждая фракция исследовалась методом энергодисперсионной рентгеновской спектроскопии на сканирующем электронном микроскопе. Магнитная фракция в основном представлена оксидом железа. В пробах бурового шлама с Шингинского месторожде- ния встречаются Ti-Fe содержащие частицы. Электромагнитная фракция проб бурового шлама выделяется наличием включений, спектр которых соответствует дисульфиду железа (минерал пирит). Также встречаются цинк-, свинец- и медь-содержащие частицы. В пробах бурового шлама, отобранных из действующих шламовых амбаров Шингинского месторождения кустовой площадки № 8 и Южно-Шингинского месторождения кустовой площадки № 3, амбара № 3, выявлены включения, спектр которых соответствует сульфату бария (минерал барит).

В исследуемых пробах бурового шлама обнаружены сферулы оксида железа и оксида свинца. Были сняты спектры, и сделаны снимки найденных сферул в режиме обратно рассеянных электронов. Результаты представлены на рис. 5, 6. Сферулы оксида железа обнаружены во всех пробах, за исключением пробы с кустовой площадки № 3, амбар № 1, ЮжноШингинского месторождения. Сферулы оксида свинца выявлены исключительно в пробах с Шингинского месторождения.

Следует отметить, что ряд минеральных фаз, встречающихся в пробах бурового шлама, совпадает с минералогическим составом образцов торфа из Васюганского болота, представленными детритовыми, аутогенными минералами [34]. К детритовым минералам относятся - кварц, полевые шпаты, ильменит, рутил, к аутогенным минералам - кальцит, оксиды железа, пирит, барит.

Так как в ходе исследования выявилось повышенное содержание ряда элементов по данным массспектрометрии с индуктивно связанной плазмой, среднее содержание химических элементов в пробах бурового шлама сравнили с содержанием этих элементов в технологических добавках, используемых при буровых работах на исследуемых месторождениях (табл. 6).

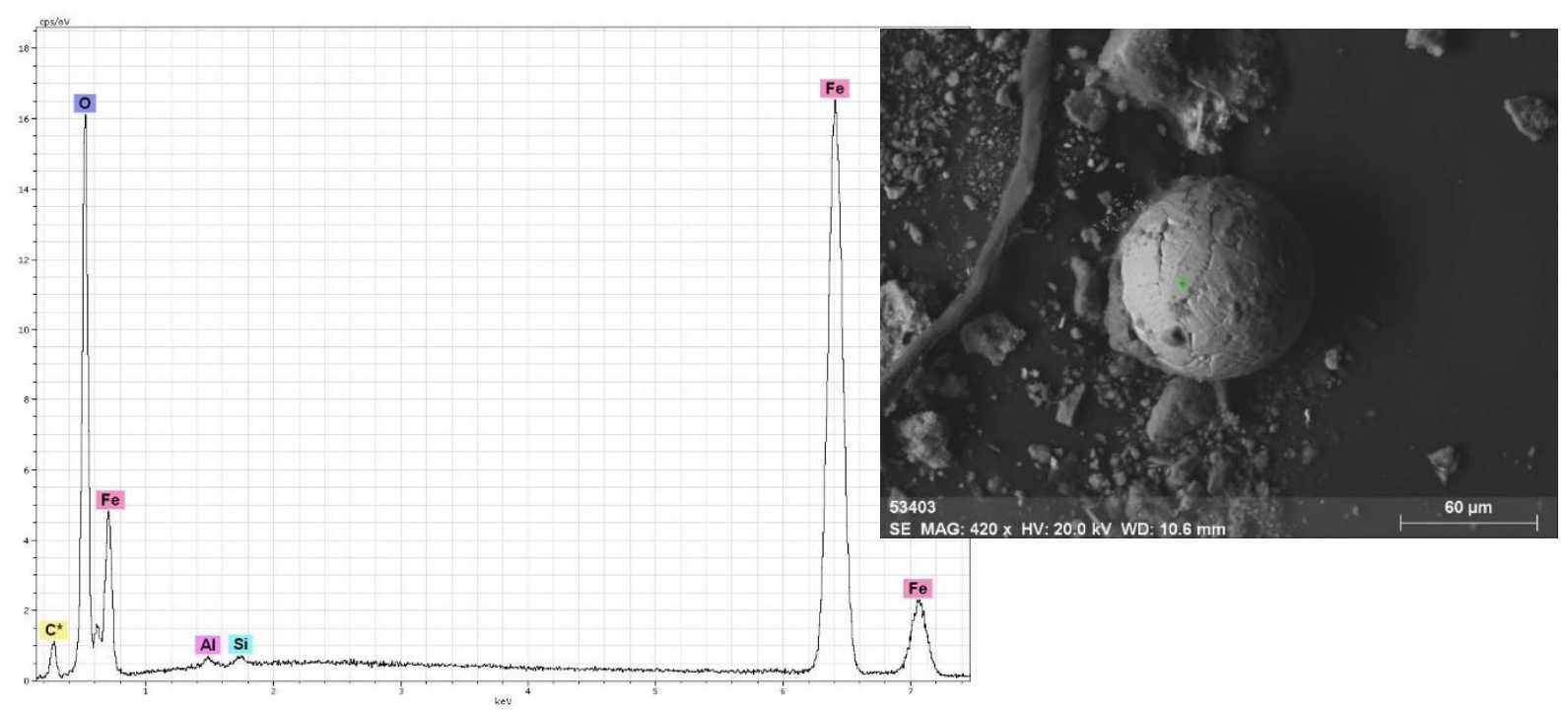

Рис. 5. Снимок в режиме обратно рассеянных электронов и спектр сферулы оксида железа размером $70 \mu \mathrm{m}$

Fig. 5. Back-scattered electron images and spectra of spherule of iron oxide, the size of the sample is $70 \mu \mathrm{m}$ 


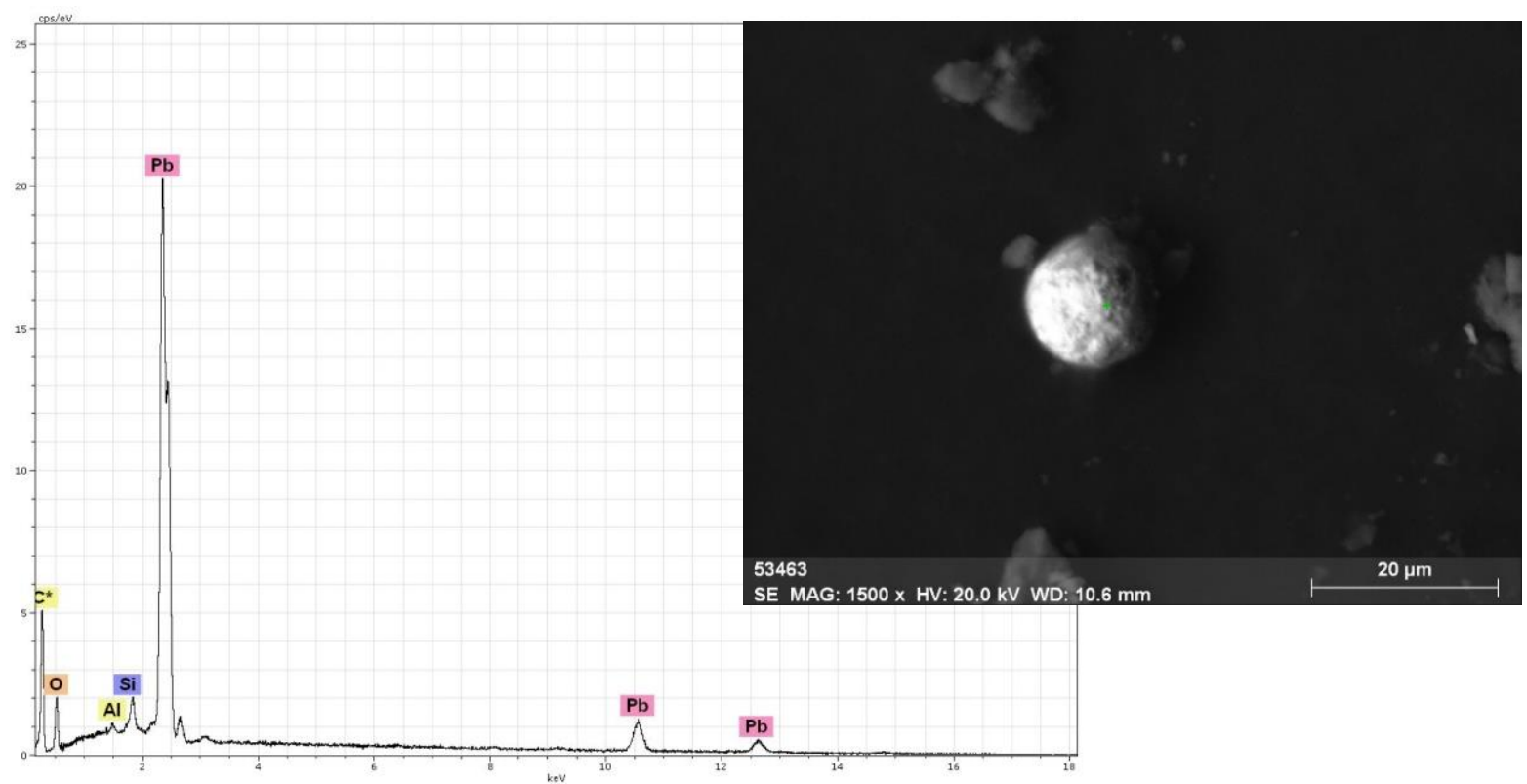

Рис. 6. Снимок в режиме обратно рассеянных электронов и спектр сферуль оксида свинца размером 15 нт Fig. 6. Back-scattered electron images and spectra of spherule of lead oxide, the size of the sample is $15 \mu \mathrm{m}$

Таблица 6. Содержание химических элементов (в мг/кг) в технологических добавках в сравнении со средним содержанием элементов в буровом иламе

Table 6. Content of chemical elements (in $\mathrm{mg} / \mathrm{kg}$ ) in technological additives in comparison with the average content of elements in drill cuttings

\begin{tabular}{|c|c|c|c|c|c|c|c|c|c|}
\hline \multicolumn{2}{|r|}{ Элементы/Elements } & $\mathrm{Ti}$ & $\mathrm{Cr}$ & $\mathrm{Fe}$ & $\mathrm{Cu}$ & $\mathrm{Zn}$ & As & $\mathrm{Ba}$ & $\mathrm{Pb}$ \\
\hline \multicolumn{2}{|r|}{$\begin{array}{c}\text { Среднее арифметическое значение по пробам бурового шлама } \\
\text { Arithmetic average for samples of drill cuttings }(n=5)\end{array}$} & 4207,2 & 91,81 & 35802,54 & 70,77 & 188,97 & 7,12 & 471,67 & 116,00 \\
\hline \multirow{7}{*}{ 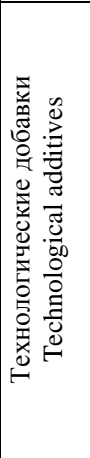 } & $\begin{array}{l}\text { Профосфат натрия кислый } \\
\text { Sodium prophosphate }\end{array}$ & 25,57 & 1,34 & 217,28 & 2,69 & 12,18 & $0,25 *$ & 0,09 & $0,005^{*}$ \\
\hline & $\begin{array}{l}\text { Понизитель фильтрации } \\
\text { Filtration reducer }\end{array}$ & 44,57 & 6,22 & 639,24 & 7,46 & 25,83 & $0,25^{*}$ & 0,08 & 0,016 \\
\hline & \begin{tabular}{|l|} 
Ингибитор глин \\
Clay inhibitor \\
\end{tabular} & 166,82 & 6,28 & 7050,53 & 4,06 & 11,24 & $0,25 *$ & 1,55 & 0,020 \\
\hline & $\begin{array}{l}\text { Полипас *R } \\
\text { Polypas *R }\end{array}$ & 8,91 & 1,94 & 130,43 & 0,85 & 0,30 & $0,25 *$ & 0,05 & $0,005^{*}$ \\
\hline & $\begin{array}{l}\text { Карбонат кальция } \\
\text { Calcium carbonate }\end{array}$ & 27,09 & 4,79 & 1130,75 & 5,15 & 15,95 & 0,52 & 0,68 & $0,005^{*}$ \\
\hline & $\begin{array}{l}\text { Добавка для бурения } \\
\text { Drilling additive }\end{array}$ & 11,51 & 3,90 & 313,01 & 1,68 & 5,01 & $0,25 *$ & 0,02 & $0,005^{*}$ \\
\hline & $\begin{array}{l}\text { Полионионовая целлюлоза } \\
\text { Polyionic cellulose }\end{array}$ & 14,32 & 3,64 & 299,83 & 2,39 & 26,61 & $0,25 *$ & 0,08 & $0,005^{*}$ \\
\hline
\end{tabular}

Установлено, что содержания элементов в технологических добавках не оказывают существенного влияния на химический состав исследуемых проб бурового шлама.

Для определения токсического эффекта буровых шламов было проведено биотестирование с использованием следующих тест-объектов: рачков Daphia magna Straus, микроводоросли Scenedesmus quadricaud (Turp.) Breb., плодовой мушки Drosophila melanogaster. Результаты постановки экспериментов приведены в табл. 7. Токсичность исследуемых проб на тест-объект Drosophila melanogaster оценивалось по соотношению полов, т. к. при постановке эксперимента морфозы у нового поколения мушек не были выявлены.

По результатам исследования, все пробы бурового шлама не оказывают токсического действия на мик- роводоросль Scenedesmus quadricauda и плодовую мушку Drosophila melanogaster. Однако для шламов Шингинского (кустовая площадка № 7) и ЮжноШингинского (кустовая площадка № 3, амбар № 1) месторождений биотестирование на тест-организме рачка Daphia magna устанавливает, что водная вытяжка из отхода оказывает вредное воздействие при кратности в 1 раз.

Как видно из таблицы, результаты биотестирования не отражают специфику накопления химических элементов. Можно предположить, что химические элементы, выявленные в повышенных концентрациях и отмеченные в концентрировании, находятся в нерастворенной форме и не влияют на тест-объект. Таким образом, исследуемые пробы бурового шлама относятся к малоопасным, практически неопасным отходам и не являются потенциально токсичными. 
Таблица 7. Результаты биотестирования буровых иламов

Table 7. Results of biotesting of drill cuttings

\begin{tabular}{|c|c|c|c|}
\hline \multirow[b]{2}{*}{ Место отбора/Sampling place } & \multicolumn{3}{|c|}{ Тест-объект/Test -object } \\
\hline & $\begin{array}{l}\text { Daphia magna } \\
\text { Straus }\end{array}$ & Scenedesmus quadricauda & $\begin{array}{c}\text { Drosophila melanogaster } \\
\text { мухи/flies }\end{array}$ \\
\hline \multirow{2}{*}{$\begin{array}{l}\text { Шингинское, } \\
\text { кустовая площадка № 7, амбар } 1 \text { (1) } \\
\text { Shinginskoe field, well pad № 7, } \\
\text { sludge pit } 1 \text { (1) }\end{array}$} & \multirow[b]{2}{*}{+} & \multirow[b]{2}{*}{-} & - \\
\hline & & & 1147 \\
\hline \multirow{2}{*}{$\begin{array}{l}\text { Шингинское, } \\
\text { кустовая площадка № 8, амбар } 1 \text { (1) } \\
\text { Shinginskoe field, well pad № } 8 \text {, } \\
\text { sludge pit } 1 \text { (1) }\end{array}$} & \multirow{2}{*}{-} & \multirow{2}{*}{-} & - \\
\hline & & & 705 \\
\hline \multirow{2}{*}{$\begin{array}{l}\text { Южно-Шингинское, } \\
\text { кустовая площадка № 3, амбар } 1 \text { (1) } \\
\text { Yuzhno-Shinginskoe field, } \\
\text { well pad №3, sludge pit } 1 \text { (1) }\end{array}$} & \multirow[b]{2}{*}{+} & \multirow[b]{2}{*}{-} & - \\
\hline & & & 937 \\
\hline \multirow{2}{*}{$\begin{array}{l}\text { Южно-Шингинское, } \\
\text { кустовая площадка № 3, амбар } 2 \text { (1) } \\
\text { Yuzhno-Shinginskoe field, } \\
\text { well pad № 3, sludge pit } 2 \text { (1) }\end{array}$} & \multirow[b]{2}{*}{-} & \multirow[b]{2}{*}{-} & - \\
\hline & & & 806 \\
\hline \multirow{2}{*}{$\begin{array}{l}\text { Южно-Шингинское, } \\
\text { кустовая площадка № 3, амбар } 3 \text { (1) } \\
\text { Yuzhno-Shinginskoe field, } \\
\text { well pad № 3, sludge pit } 3 \text { (1) }\end{array}$} & \multirow[b]{2}{*}{-} & \multirow[b]{2}{*}{-} & - \\
\hline & & & 835 \\
\hline \multicolumn{4}{|l|}{ Water extract has a } \\
\hline Не оказывает вред & 3ue/No harmful e & & \\
\hline
\end{tabular}

Примечание: в скобках-количество проб.

Note: the amount of samples is given in brackets.

\section{Выводы}

Обобщая вышеизложенные результаты исследования по установлению геохимической и минералогической специфики буровых шламов, на примере Шингинского и Южно-Шингинского месторождений, можно отметить некоторые особенности.

1. Исследуемые пробы обладают схожим минералогическим составом, что указывает на одинаковое образование исходных вмещающих пород. Максимальная доля в составе буровых шламов приходится на кварц и калинатровые полевые шпаты. Глинистая составляющая представлена каолинитом, иллитом и вермикулитом.

2. В буровом шламе, отобранном из шламовых амбаров Шингинского и Южно-Шингинского месторождений, фиксируются повышенные концентрации $\mathrm{Pb}$, $\mathrm{Zn}, \mathrm{Cu}$ относительно среднего состава верхней части континентальной земной коры и осадочных горных пород в целом (по Н.А. Григорьеву) и содержания химических элементов почвах горизонтов В, C Baсюнагской равнины (по А.И. Сысо).

3. Суммарный показатель загрязнения, рассчитанный по кларку концентрации, показывает, что преимущественно пробы шлама относятся к низкой степени загрязнения, а в отдельных амбарах (Шингинское месторождение, кустовая площадка № 8 и Южно-Шингинское месторождение кусто-

\section{СПИСОК ЛИТЕРАТУРЫ}

1. Московченко Д.В., Дожорукова С.Л. Последствия буровых работ на севере Тюменской области // Экология и промышленность России. - 2002. - № 9. - С. 27-30. вая площадка № 3, амбар № 3) - к средней степени загрязнения, что подтверждает тот факт, что данные амбары находились в стадии эксплуатации на момент отбора.

4. Метод энергодисперсионной рентгеновской спектроскопии на сканирующем электронном микроскопе выявил минеральные фазы таких элементов, как $\mathrm{Fe}, \mathrm{Pb}, \mathrm{Zn}, \mathrm{Ba}, \mathrm{Cu}$, Ti. Были обнаружены частицы железа и свинца характерной сферической формы.

5. По результатам биотестирования все пробы шлама не оказывают токсического действия на микроводоросль Scenedesmus quadricauda и плодовую мушку Drosophila melanogaster. Однако для буровых шламов с действующих амбаров Шингинского (кустовая площадка № 7) и Южно-Шингинского (кустовая площадка № 3, амбар № 1) месторождений биотестирование на тест-организме рачка Daphia magna устанавливает вредное воздействие при кратности в 1 раз.

6. По результатам токсикологического анализа методом биотестирования, выявлено, что исследуемые пробы бурового шлама относятся к малоопасным, практически неопасным отходам и не являются потенциально токсичными.

Исследования были выполнены с использованием научного оборудования Центра коллективного использования ТПУ.

2. Соромотин А.В. Воздействие добычи нефти на таежные экосистемы Западной Сибири. - Тюмень: Изд-во Тюменского государственного университета, 2010. -320 c.

3. Пашкевич М.А., Куликова М.А., Экологический мониторинг. - СПб.: Национальный минерально-сырьевой университет «Горный», 2013. - 100 с. 
4. Экологическое сопровождение разработки нефтегазовых месторождений. Вып. 2. Мониторинг природной среды на объектах нефтегазового комплекса: аналитический обзор / А.Г. Гендрин, Г.А. Надоховская, Н.К. Смирнова, В.П. Середина, А.И. Непотребный, А.Г. Киселев, Е.С. Русинова, А.М. Худобец, А.А. Серых, А.Н. Чемерис. - Новосибирск: Государственная публичная научно-техническая библиотека Сибирского отделения Российской академии наук; ТомскНИПИнефть ВНК, 2006. - 123 с.

5. Савичев О.Г., Бернатонис П.В., Бернатонис В.К. Геохимические условия размещения и утилизации отходов бурения в торфяно-болотных геосистемах Сибири // Вестник Томского государственного университета. - 2013. - № 375. - С. 183-186.

6. Влияние шламовых амбаров на геохимическое состояние болотных экосистем в бассейне реки Васюган / В.А. Базанов, О.Г. Савичев, Д.В. Волостнов, Б.А. Егоров, А.О. Крутовский, Е.Г Язиков. // Известия Томского политехнического университета. - 2004. - Т. 30. - № 2. - С. 72-75.

7. Savichev O.G., Matveenko I.A., Savchenko D.V. Changes in chemical composition of drilling waste water in taiga zone of Western Siberia (the Russian Federation) on the basis of thermodynamic approach // IOP Conf. Series: Earth and Environmental Science. $-2016 .-7 \mathrm{p}$.

8. Characterization of drilling waste from shale gas exploration in Centraland Eastern Poland / M. Mikos-Szymańska, P. Rusek, K. Borowik, M. Rolewicz, P. Bogusz // Environmental Science and Pollution Research. - 2018. - V. 25. - Iss. 36. - P. 35990-36001.

9. Kujawska J., Cel W. Mobility of metals from drill cuttings // International Journal of Waste Resources. - 2017. - V. 7. - P. 1-3.

10. Onwukwe S. I., Nwakaudu M. S. Drilling wastes generation and management approach // International Journal of Environmental Science and Development. - 2012. - V. 3. - № 3. - P. 252-257.

11. Drill cutting accumulations in the Northern and Central North Sea: a review of environmental interactions and chemical fate / E. Breuer, A.G. Stevenson, J.A. Howe, J. Carroll, G.B. Shimmield // Marine Pollution Bulletin. - 2004. - V. 48. - P. 12-25.

12. Frost T.K., Neff J. Toxicity of drilling discharges // Report Environmental Risk Management System. - Trondheim, SINTEF Publ. 2006. - V. 4. -214 p.

13. Ifeadi Ch.N. The treatment of drill cuttings using dispersion by chemical reaction (DCR) // Health, Safety \& Environment (HSE) International Conference on Oil and Gas Industry. Port Harcourt, 2004. - P. 1-12.

14. Neff J.M. Composition, environmental fates and biological effects of water based drilling muds and cuttings discharged to the marine environment: a synthesis and annotated bibliography. Report to Petroleum Environmental Research Forum (PERF) and American Petroleum Institute. - Daksberi: Battelle Publ., 2005. - 73 p.

15. Nabhani N., Khaje E. Environmental aspect of oil and water-based offshore drilling muds and cuttings // International Journal of Mechanical and Production Engineering. - 2015. - V. 3. - Iss. 4. P. 14-19.

16. Соромотин А.В., Пислегин Д.В. Тяжелые металлы в донных отложениях шламовых амбаров геологоразведочных скважин Западной Сибири // Геоэкология. Инженерная геология. Гидрогеология. Геокриология. - 2015. - № 6. - С. 514-520.

17. Матвиенко В.В., Кузнецов В.А., Цеханский М.В. К вопросу о современных методах переработки и утилизации отходов бурения // Нефть и газ Сибири. - 2017. - № 3. - С. 146-151.

18. Babken M.B., Chudnova T.A., Shapovalov D.A. Environmental justification of the use of drill cuttings in the soil // International agricultural journal. - 2019. - № 1. - P. 50-55.
19. Stuckman M., Lopano C.L., Hakala J.A. Trace metal distribution and mobility in drill cuttings from Marcellus shale gas extraction // Office of Scientific and Technical Information. - 2016. URL: https://www.osti.gov/servlets/purl/1344480 (дата обращения 23.07.2019)

20. Хаустов А.П., Редина М.М. Охрана окружающей среды при добыче нефти. - М.: Дело, 2006. - 552 с.

21. Минигазимов Н.С., Минигазимов Р.Ш. Новая информация о токсичности нефтесодержащих отходов // Уральский экологический вестник. - 2014. - № 2. - Р. 31-36.

22. Павлова Е.Ю. Оценка экологической безопасности размещения бурового шлама на территории Ханты-Мансийского автономного округа-Югры // Международный студенческий вестник. - 2015. - № 4. - С. 676-679.

23. Оценка цитотоксичности образцов бурового шлама, собранных на территории амбара, в природных условиях ХМАО-Югры / А.В. Нехорошева, И.Ф. Киржаков, И.И. Авдеева, P.Р. Ахмеджанов // Известия Самарского научного центра Российской академии наук. -2015 . - Т. 17. - № 5. - С. 690-694.

24. Пичугин Е.А., Шенфельд Б.Е. К вопросу различия буровых и нефтяных шламов // Экология и промышленность России. 2017. - T. 21. - № 7. - C. 14-19.

25. Балаба В.И. Обеспечение экологической безопасности строительства скважин на море // Бурение и нефть. - 2004. - № 1. C. $18-21$.

26. Патин С.А. Нефть и экология континентального шельфа. - М.: ВНИРО, 2001. $-247 \mathrm{c}$.

27. Муртазин Д.Г., Пищулева А.В., Губаев А.Р. Применение кластеризации амплитудных спектров в условиях сложнопрогнозируемого геологического разреза по данным сейсморазведки 3D // Рнонефть. Профессионально о нефти. - 2018. № 1. - C. $28-32$.

28. Даненберг Е.Е., Белозеров В.Б., Брылина Н.А. Геологическое строение и нефтегазоносность верхнеюрско-нижнемеловых отложений юго-востока Западно-Сибирской плиты (Томская область). - Томск: Изд-во Томского политехнического университета, 2006. $-291 \mathrm{c.}$

29. ПНД Ф 12.1:2:2.2:2.3:3.2-03 Методические рекомендации. Отбор проб почв, грунтов, донных отложений, илов, осадков сточных вод, шламов промышленных сточных вод, отходов производства и потребления. - М.: ФБУ Федеральный центр анализа и оценки техногенного воздействия, 2014. - 15 с

30. Григорьев Н.А. Распределение химических элементов в верхней части континентальной коры. - Екатеринбург: УрО РАН, 2009. $-382 \mathrm{c}$

31. Геохимия окружающей среды / Ю.Е. Сает, Б.А. Ревич, Е.П. Янин, Р.С. Смирнова, И.Л. Башаркевич, Т.Л. Онищенко, Л.Н. Павлова, Н.Я. Трефилова, А.И. Ачкасов, С.Ш. Саркисян. М.: Недра, 1990. -335 c.

32. Гершензон С.М. Основы современной генетики. - Киев: Наукова думка, 1983. $-560 \mathrm{c}$.

33. Сысо А.И. Закономерности распределения химических элементов в почвообразующих породах и почвах Западной Сибири / отв. ред. И.М. Гаджиев. - Новосибирск: Изд-во СО РАН, 2007. $-277 \mathrm{c}$.

34. Authigenic and detrital minerals in peat environment of Vasyugan swamp, Western Siberia / M. Rudmin, A. Ruban, O. Savichev, A. Mazurov, A. Dauletova, O. Savinova // Minerals. - 2018. № 8. $-13 \mathrm{p}$.

Поступила 14.11.2019 2.

\section{Информация об авторах}

Климова А.A., аспирант отделения геологии Инженерной школы природных ресурсов Национального исследовательского Томского политехнического университета.

Язиков $\boldsymbol{E . \Gamma . , ~ д о к т о р ~ г е о л о г о - м и н е р а л о г и ч е с к и х ~ н а у к , ~ п р о ф е с с о р ~ о т д е л е н и я ~ г е о л о г и и ~ И н ж е н е р н о и ̆ ~ ш к о л ы ~ п р и - ~}$ родных ресурсов Национального исследовательского Томского политехнического университета.

Шайхиев И.Р., кандидат геолого-минералогических наук, ведущий инженер по охране труда и промышленной безопасности отдела охраны труда, промышленной и пожарной безопасности Управления производственной безопасности Общества с ограниченной ответственностью «Газпромнефть-Восток». 
UDC 622.323'156(571.16)

\title{
MINERALOGICAL AND GEOCHEMICAL PARTICULARITY OF DRILL CUTTINGS FROM OIL FIELDS ON THE EXAMPLE OF OBJECTS OF THE TOMSK REGION
}

\author{
Alena A. Klimova1, \\ klimovalena777@mail.ru \\ Egor G. Yazikov', \\ yazikoveg@tpu.ru \\ Ildar R. Shaikhiev², \\ ildar.shaihiev@mail.ru \\ 1 National Research Tomsk Polytechnic University, \\ 30, Lenin avenue, Tomsk, 634050, Russia. \\ 2000 «Gazpromneft-Vostok», \\ 13a, bld. 1, Nakhimova street, Tomsk, 634045, Russia.
}

\begin{abstract}
The relevance of the research is in poorly studied mineralogical, elemental composition and toxicity of drill cuttings formed during the construction of wells in oil fields.

The main aim of the research is to identify the geochemical and mineralogical particularity of drill cuttings, to determine the toxicity of this type of waste using modern research methods.

Methods: X-ray powder diffraction; inductively coupled plasma mass spectrometry; scanning electron microscope; bioassay.

Results. Common minerals, such as quartz, albite, muscovite and calcite, were determined in the studied samples of drill cuttings that indicates a similar composition of the original host rocks. The geochemical specificity of drill cuttings expressed in increased concentration of chemical elements such as $\mathrm{Pb}, \mathrm{Zn}, \mathrm{Cu}$, was revealed. Mainly, the elements belong to heavy metals of I, II and III hazard class. The value of the total pollution indicator shows that most samples of drill cuttings are of low pollution. However, the samples from existing sludge pits are characterized by medium pollution. The identified mineral phases are represented by oxides of iron, lead, zinc, iron sulfide, barium sulfate. Spherical particles of iron and lead were discovered. In general, drill cuttings samples have not toxic effects on test objects: Daphia magna, Scenedesmus quadricauda, Drosophila melanogaster. At the same time, samples from existing sludge pits have an effect on the test organism Daphia magna. In this way, the studied samples of drill cuttings are low-hazardous, practically non-hazardous waste, and are not potentially toxic.
\end{abstract}

\section{Key words:}

Drill cuttings, sludge pits, well pad, oil field, elemental composition, heavy metals, bioassay.

The research was carried out with the use of scientific equipment of the Sharing centre at TPU.

\section{REFERENCES}

1. Moskovchenko D.V., Dozhorukova S.L. The consequences of drilling operations in the North of the Tyumen region. Ecology and Industry of Russia, 2002, no. 9, pp. 27-30. In Rus.

2. Soromotin A.V. Vozdeystvie dobychi nefti na taezhnye ekosistemy Zapadnoy Sibiri [Impact of oil production on taiga ecosystems of Western Siberia]. Tyumen, Tyumen state university Publ., 2010. $320 \mathrm{p}$.

3. Pashkevich M.A., Kulikova M.A. Ekologicheskiy monitoring [Environmental monitoring]. St-Petersburg, National Mineral Resources University «Gorny» Publ., 2013. 100 p.

4. Gendrin A.G., Nadokhovskaya G.A., Smirnova N.K., Seredina V.P., Nepotrebny A.I., Kiselev A.G., Rusinova E.S., Khudobets A.M., Serykh A.A., Chemeris A.N. Ekologicheskoe soprovozhdenie razrabotki neftegazovykh mestorozhdeniy. Vypusk 2. Monitoring prirodnoy sredy na obektakh neftegazovogo kompleksa: analiticheskiy obzor [Environmental escort for exploitation oil and gas deposits. Iss. 2. Natural state monitoring on the objects of oil and gas complexes: analytical review]. Novosibirsk, State public science-technical library of Siberian branch of RAS; TomskNIPIneft VNK Publ., 2006. 123 p.

5. Savichev O.G., Bernatonis P.V., Bernatonis V.K. Geochemical conditions of disposal and utilization of drilling waste in the peat bog ecosystems of Siberia. Bulletin of the Tomsk Polytechnic University, 2013, vol. 375, no. 375, pp. 183-186. In Rus.

6. Bazanov V.A., Savichev O.G., Volostnov D.V., Egorov B.A., Krutovskiy A.O., Yazikov E.G. The influence of sludge pits on the geochemical state of wetland ecosystems in the Vasyugan river basin. Bulletin of the Tomsk Polytechnic University, 2004, vol. 30, no. 2, pp. 72-75. In Rus.

7. Savichev O.G., Matveenko I.A., Savchenko D.V. Changes in chemical composition of drilling waste water in taiga zone of Western Siberia (the Russian Federation) on the basis of thermodynamic approach. IOP Conference Series: Earth and Environmental Science, 2016. 7 p.

8. Mikos-Szymańska M., Rusek P., Borowik K., Rolewicz M., Bogusz P., Characterization of drilling waste from shale gas exploration in Centraland Eastern Poland. Environmental Science and Pollution Research, 2018, vol. 25, no. 36, pp. 35990-36001.

9. Kujawska J., Cel W. Mobility of metals from drill cuttings. International Journal of Waste Resources, 2017, vol. 7, pp. 1-3.

10. Onwukwe S.I., Nwakaudu M.S. Drilling wastes generation and management approach. International Journal of Environmental Science and Development, 2012, vol. 3, no. 3, pp. 252-257.

11. Breuer E., Stevenson A.G., Howe J.A., Carroll J., Shimmield G.B. Drill cutting accumulations in the Northern and Central North Sea: a review of environmental interactions and chemical fate. Marine Pollution Bulletin, 2004, vol. 48, pp. 12-25.

12. Frost T.K., Neff J. Toxicity of drilling discharges. Report Environmental Risk Management System. Trondheim, SINTEF Publ., 2006, vol. 4, 214 p.

13. Ifeadi Ch.N. The treatment of drill cuttings using dispersion by chemical reaction (DCR). Health, Safety \& Environment (HSE) International Conference on Oil and Gas Industry. Port Harcourt, 2004. pp. 1-12. 
14. Neff J.M. Composition, environmental fates and biological effects of water based drilling muds and cuttings discharged to the marine environment: a synthesis and annotated bibliography. Report to Petroleum Environmental Research Forum (PERF) and American Petroleum Institute. Daksberi, Battelle Publ., 2005. 73 p.

15. Nader Nabhani, Esmaeel Khaje. Environmental aspect of oil and water-based offshore drilling muds and cuttings. International Journal of Mechanical and Production Engineering, 2015, vol. 4, pp. $1-6$.

16. Soromotin A.V., Pislegin D.V. Heavy metals in bottom sediments of sludge pits in exploration wells in the Western Siberia. Geoecology. Engineering geology. Hydrogeology. Geocryology, 2015, no. 6, pp. 514-520. In Rus.

17. Matveenko V.V., Kuznetsov V.A., Tsekhanskiy M.V. K voprosu o sovremennykh metodakh pererabotki i utilizatsii otkhodov bureniya [On the issue of modern methods of processing and disposal of drilling waste]. Neft i gaz Sibiri, 2017, no. 3, pp. 146-151.

18. Babken M.B., Chudnova T.A., Shapovalov D.A. Environmental justification of the use of drill cuttings in the soil. International agricultural journal, 2019, no. 1, pp. 50-55.

19. Stuckman M., Lopano C.L., Hakala J.A. Trace metal distribution and mobility in drill cuttings from Marcellus shale gas extraction. Office of Scientific and Technical Information, 2016. Available at: https://www.osti.gov/servlets/purl/1344480 (accessed 23 July 2019).

20. Khaustov A.P., Redina M.M. Okhrana okruzhayushchey sredy pri dobychi nefti [Environmental protection in oil production]. Moscow, Delo Publ., 2006. 552 p.

21. Minigazimov N.S., Minigazimov R.Sh. The new information on the toxicity of oily waste. Ecological bulletin of Ural, 2014, no. 2, pp. 31-36. In Rus.

22. Pavlova E.Yu. Otsenka ekologicheskoy bezopasnosti razmeshcheniya burovogo shlama na territorii Khanty-mansiyskogo avtonomnogo okruga-Yugry [Assessment of the environmental safety of the placement of drill cuttings in the territory of the Khanty-Mansiysk Autonomous Okrug-Yugra]. Mezhdunarodny studencheskiy nauchny vestnik, 2015, no. 4, pp. 676-679.

23. Nehorosheva A.V., Kirzhakov I.F., Avdeeva I.I., Akhmedzhanov R.R. Cytotoxicity estimation of drilling slime sample, collected in the territory of barn, in nature of Khanty-Mansi autonomous district Urga. Bulletin of the Samara Scientific Center of the Russian Academy of Sciences, 2015, vol. 17, no. 5, pp. 690-694. In Rus.

24. Pichugin E.A., Shenfeld B.E. To the issue of differences of drilling sludge and oil sludge. Ecology and Industry of Russia, 2017, vol. 21, no. 7, pp. 14-19. In Rus.
25. Balaba V.I. Ensuring environmental safety of wells construction on the sea. Drilling and oil, 2004, no. 1, pp. 18-21. In Rus.

26. Patin S.A. Neft i ekologiya kontinentalnogo shelfa [Oil and continental shelf ecology]. Moscow, VNIRO Publ., 2017, vol. 1, 326 p.

27. Murtazin D.G., Pishchuleva A.V., Gubaev A.R. Application of amplitude spectra clustering with $3 \mathrm{~d}$ seismic data under conditions of difficult to forecast geological section. PROneft. Professionals about oil, 2018, no. 1, pp. 28-32. In Rus.

28. Danenberg E.E., Belozerov V.B., Brylina N.A. Geologicheskoe stroenie $i$ neftegazonosnost verkhneyursko-nizhnemelovykh otlozheniy yugo-vostoka Zapadno Sibirskoy plity (Tomskaya oblast) [Geological structure and oil and gas potential of the Upper Jurassic-Lower Cretaceous sediments of the southeast of the WestSiberian Plate (Tomsk Region)]. Tomsk, TPU Publ., 2006. 291 p.

29. PND F 12.1:2:2.2:2.3:3.2-03 Metodicheskie rekomendatsii. Otbor prob pochv, gruntov, donnykh otlozheniy, ilov, osadkov stochnykh vod, shlamov promyshlennykh stochnykh vod, otkhodov proizvodstva i potrebleniya [Methodical recommendations. Sampling of soil, soil, sediment, silt, sewage sludge, industrial wastewater sludge, production and consumption waste]. Moscow, Federal State Institution Federal Center for Analysis and Assessment of Technogenic Impact Publ., 2014. 15 p.

30. Grigoriev N.A. Raspredelenie khimicheskikh elementov v verkhney chasti kontinentalnoy kory [Chemical element distribution in the upper continental crust]. Ekaterinburg, UrO RAN Publ., 2009. $382 \mathrm{p}$.

31. Saet Yu.E., Revich B.A., Yanin E.P., Smirnova R.S., Basharkevich I.L., Onishchenko T.L., Pavlova L.N., Trefilova N.Ya., Achkasov A.I., Sarkisyan S.Sh. Geokhimiya okruzhayushchey sredy [Environmental geochemistry]. Moscow, Nedra Publ., 1990. $335 \mathrm{p}$.

32. Gershenzon S.M. Osnovy sovremennoy genetiki [Foundations of modern genetics]. Kiev, Naukova dumka Publ., 1983. 560 p.

33. Syso A.I. Zakonomernosti raspredeleniya khimicheskikh elementov $v$ pochvoobrazuyushchikh porodakh i pochvakh Zapadnoy Sibiri [Patterns of distribution of chemical elements in soilforming rocks and soils of Western Siberia.]. Novosibirsk, SO RAN Publ., 2007. 277 p.

34. Rudmin M., Ruban A., Savichev O., Mazurov A., Dauletova A., Savinova O. Authigenic and detrital minerals in peat environment of Vasyugan Swamp, Western Siberia. Minerals, 2018, no. 8, pp. 1-13.

Received: 14 November 2019.

\section{Information about the authors}

Alena A. Klimova, postgraduate student, National Research Tomsk Polytechnic University.

Egor G. Yazikov, Dr. Sc., professor, National Research Tomsk Polytechnic University.

Ildar R. Shaikhiev, Cand. Sc., leading engineer for labor protection and industrial safety, Gazpromneft-Vostok. 